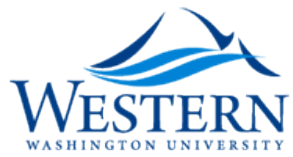

Western Washington University

Western CEDAR

Winter 2006

\title{
Haunted Collections: Vernon Lee and Ethical Consumption
}

Kristin Mary Mahoney

Western Washington University, kristin.mahoney@wwu.edu

Follow this and additional works at: https://cedar.wwu.edu/english_facpubs

Part of the English Language and Literature Commons

\section{Recommended Citation}

Mahoney, Kristin Mary, "Haunted Collections: Vernon Lee and Ethical Consumption" (2006). English Faculty and Staff Publications. 6. https://cedar.wwu.edu/english_facpubs/6

This Article is brought to you for free and open access by the English at Western CEDAR. It has been accepted for inclusion in English Faculty and Staff Publications by an authorized administrator of Western CEDAR. For more information, please contact westerncedar@wwu.edu. 


\title{
ชิ․
}

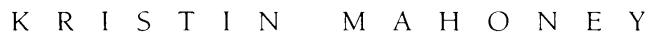 \\ Haunted Collections: Vernon Lee and Ethical Consumption}

\begin{abstract}
I believe that's the last bit of bric-à-brac I shall ever buy in my life (she said, closing the Renaissance casket) - that and the Chinese dessert set we have just been using. The passion seems to have left me utterly. And I think I can guess why. At the same time as the plates and the little coffer I bought a thing-I scarcely know whether I ought to call it a thing-which put me out of conceit with ferreting about among dead people's properties.
\end{abstract}

—Vernon Lee, "The Doll"

VERnON LeE'S "The DOLl." is the story of a collector's reformation. The thing (which perhaps should not be called a thing) that is responsible for putting the collector "out of conceit with ferreting about among dead people's properties" is a doll that once belonged to a widowed count. The count had spent hours each day holding this life-sized mannequin, which had been dressed in his wife's clothing and a wig fashioned from her hair. When the count died, the doll was cast into a closet. The collector encounters the doll while shopping for bric-abrac and presses her curiosity dealer for its history. Indignant that this tragic object should be left to gather dust in a closet, she purchases the doll in order to burn it. Burning the doll cures her insatiable desire for bric-a-brac and puts "an end to [the doll's] sorrows." The historical contextualization of this object has remedied the narrator's taste for collecting and has facilitated the liberation of an object from degradation and disregard. In this essay I read Lee's fiction as an ethical instruction manual for the modern consumer, as allegorical directions for the recontextualization or re-auraticization of objects. I argue that Lee formulates an ethical corrective to the subjectivism of modern consumer practices in her ghost stories. The heroes of these stories model a method of appreciation that acknowledges the historical otherness of the cultural relic and grants the object a separate and distinct identity, allowing it to exceed its utility as an indicator of taste. This

Criticism, Winter 2006, Vol. 48, No. 1, pp. 39-67

Copyright (C) 2007 Wayne State University Press, Detroit, MI 48201 
praxis of ethical consumption is set up as an alternative to aggressive modes of consumption that threaten to absorb and assimilate difference. Again and again in Lee's short fiction, characters are awakened to the sanctity, the otherness, the separateness of objects, and these ethical awakenings are often the result of what I refer to as "historicized consumption."

Lee's mode of historicized consumption is considered here in relation to the Victorian tradition of moral thinking about consumption from which it emerged. Recent work, by Peter Gurney, Deborah Cohen, Carolyn Lesjak, and Jennifer Wicke, for example, has complicated the story of the rise of mass consumption in the late nineteenth and early twentieth centuries by acknowledging countermovements, such as working-class cooperative culture or moral interior decorating, that attempted to moralize the market, or by examining the manner in which consumption and pleasure were reformulated in terms of their positive possibilities by Oscar Wilde or the members of the Bloomsbury Group. ${ }^{3}$ Reading Lee's praxis of historicized appreciation in relationship to the ongoing lateVictorian conversation concerning the politics of consumption in which Lee participated, this essay similarly argues not only that consumption has a history but also that consumption is not always necessarily opposed to history and ethics. ${ }^{4}$ During the latter half of the nineteenth century, aesthetes and economists exhibited a willingness to think through rather than against the transformations occurring in their culture, to accede to the overwhelming emphasis on consumption in the late-Victorian period while actively and pragmatically responding to the elision of history and ethics that accompanies modern consumerism. ${ }^{5}$ Ruskinian aesthetics, Paterian spectatorship of history, and the ethical strain in Alfred Marshall's neoclassical economic theory assist Lee as she reenvisions consumption as an act that "in expounding the beautiful things of the past, ... [adds] to the beautiful things of the present." Lee's attempt to infuse consumer practices with a sense of morality and history serves here as a representative example of lateVictorian pragmatic compromises with a culture of consumption and as an indication that the late Victorians' increasing concern with consumption does not amount to a capitulation to consumerist ideology.

While Lee's praxis of ethical consumption should be understood as representative of and in relation to the late-Victorian aesthetic and economic thinking from which it emerged, I also argue here for the peculiarity of Lee's method of moral appreciation. Her very first publication, Les Aventures d'une Pièce de Monnaie (1870), published when she was only fourteen years old, is an imaginary portrait of a Victorian numismatist's antique coin, a biography of an object's creation and travels before it came to lie still in a collection. This piece of juvenilia, which insists that objects have their own histories, that they were produced at a certain time, and that attention to the fact that they have led existences independent from our own will allow us to perceive them in a finer and more correct way, articulates a set of concerns that serve as a foundation for Lee's later think- 
ing on ethics and aesthetics. ${ }^{7}$ Lee moves from an emphasis on art history in her early works to an interest in psychological aesthetic theory in her later scholarship, but her treatment of objects throughout her career implies that the question cannot simply be "What is this song or picture, this engaging personality presented in life or in a book, to me?" One must also consider, "How does my manner of consuming affect this picture, this statue, this book?"9 Lee's sensitivity to the separate life of objects constitutes an implicit critique of the ideological foundations of modern consumerism. Gordon Bigelow has recently argued that the "humanistic grounds" of most Victorian critiques of capitalism and political economics only served to "solidify the central assumptions of modern, neoclassical economics: the unique integrity of the subject and the authenticity of its behavior on the market."]0 Lee's distaste for modes of consumption that degrade and decontextualize objects serves to undermine this overwhelming privileging of the desiring subject. She seeks to reanimate objects and restore to them "a life that the subject must catalyze but cannot contain." "Lee's sensitivity to what Bill Brown refers to as the "thingness" of objects, to the manner in which objects can exceed the needs and desires of the perceiving subject, opens up the possibility for ethical interactions that are not based in domination. ${ }^{12}$ Drawing on Bigelow's argument that Victorian critiques of market society that rely upon a privileging of the desiring subject reinforce the very structures they are designed to critique, I read Lee's sensitivity to the otherness of the object in her praxis of historicized consumption as a significant and compelling alternative to conventional lateVictorian critiques of consumerism.

\section{Ethics, History, and the Late-Victorian Consumer}

Early in her literary career, Vernon Lee reached the dark, Arnoldian conclusion that grand artistic production of the sort that occurred in ancient Greece or in the Renaissance was no longer possible in the Victorian period, and that consequently "artistic appreciation" was the "special domain" of the nineteenth century. In her review "Taine's Philosophy of Art," published in the British Quarterly Review in 1878, Lee draws from Hippolyte Taine's characterization of modern civilization and its effects on the modern subject in "Philosophie de l'Art en Grèce" (1869) to argue that art produced to satisfy the fractured, insatiable, shock-ridden modern consciousness will never attain perfection, so the responsibility of the modern individual is the development of the capacity for appreciation of artworks of the past. ${ }^{13}$ However, at present the public's capacity to appreciate art objects is weak and underdeveloped, for "the public have... become incapable of appreciation, intense and almost instinctive, like that of the days of artistic progress and perfection," and "art is too generally regarded as an agreeable occupation for leisure moments, and its works as pleasant playthings, which, like chessmen, can be turned and polished by dexterous persons for their 
amusement." ${ }^{14}$ Late-Victorian culture, then, is caught at an impasse, wherein aesthetic production is impossible and the public's capacity for appreciation of art has atrophied. According to Lee, however, the aesthetician and the art historian may lead the public out of this bind, for while "the works of the aesthetician and the art-historian ... cannot indeed instruct us how to produce masterpieces, ... they can teach us how to enjoy them." 15

Lee's emphasis on aesthetic consumption rather than artistic production might at first glance seem to fit neatly into the narrative recounted in Regenia Gagnier's The Insatiability of Human Wants. Gagnier focuses on the latenineteenth-century shift in economic discourse due to which consumer desire came to be understood as the primary determinant of value, consumer choice ceased to be a moral category, and value was no longer comparable across persons. This shift, referred to as the "marginal revolution," resulted from the nearly simultaneous publication of three works-William Stanley Jevons's Theory of Political Economy (1871), Léon Walras's Elements of Pure Economics (1874), and Carl Menger's Principles of Economics (1871), all of which emphasized the relationship between exchange value and marginal utility. The theory of marginal utility asserts that the most important element of consumer choice is the last unit of consumption, the amount of satisfaction derived from consuming one additional unit of a product. With each additional unit, the consumer derives less satisfaction, and consequently the value of that unit will diminish. For example, a person who is parched will value a glass of lemonade far more than a person who has already had three glasses. Neoclassical economics is based upon a subjective theory of value, as objects are only valuable according to how much they are desired. By arguing that consumer desire plays such an important part in the determination of value, these theorists exclude concern with production, with labor and laborers, from economic theory. In addition, neoclassical economic theorists tend to argue that questions of ethics or morality should not preoccupy economists. Gagnier argues that this shift in economic discourse is paralleled in the turn from a normative aesthetics concerned with either the intersubjective and the communal (the high-Victorian novel) or the conditions of creativity and production (Ruskin and Morris) to a formalist aesthetics of taste, pleasure, subjectivism, and consumption (Pater). ${ }^{16}$

Attending to the treatment of consumption in the works of Vernon Lee allows for unique insight into the connection between these parallel shifts in economic and aesthetic theory, because she actively engages with the latest developments in both disciplines. However, Lee cannot be described as submitting uncritically to this transition. Though she is highly preoccupied with the act of consumption in both her fiction and her aesthetic theory, in the 1880s and 1890s, she is in fact caught in a conflict between "normative" and "formalist" strains of aesthetic and economic thinking. Neither blindly capitulating to the shift Gagnier describes nor retreating nostalgically from new ideas about desire, she 
engages with Walter Pater's notions of aesthetic pleasure and neoclassical ideas about value while retaining elements of John Ruskin's ideas about morality and political economy's interest in contexts of production.

Though normative and formalist aesthetic theories draw Lee in very different directions, she is finally able to forge a compromise between these divergent lines of thought and theorize a mode of aesthetic pleasure that ethical behavior enlarges and intensifies. In her early aesthetic writings, such as Belcaro (1881), Lee articulates an aestheticist credo that echoes Walter Pater's assertion that "art comes to you proposing frankly to give nothing but the highest quality to your moments as they pass." She argues that "beauty, in itself, is neither morally good nor morally bad; it is aesthetically good, even as virtue is neither aesthetically good nor aesthetically bad, but morally good." She initially rejects Ruskin's particular brand of aesthetic morality, arguing that "he has made the enjoyment of mere beauty a base pleasure requiring a moral object to purify it, and in so doing, he has destroyed its own purifying power." 17 According to Lee's early aesthetic theory, aesthetic experience is good because, and only because, it is a source of pleasure. However, Lee qualified and complicated the arguments in Belcaro over the next three decades. Miss Brown (1884), Lee's novelistic satire of the Aesthetic movement, indicates that as Lee became more critical of aestheticism's hedonistic tendencies, her attachment to the "art for art's sake" credo became more complex. ${ }^{18}$ Her understanding of Ruskin seems to have followed a similar route. ${ }^{19}$ As her aesthetic thinking develops, she moves toward a reconciliation between Ruskinian morality and the particular brand of Paterian aestheticism articulated in the "Conclusion" to The Renaissance. In a "Valedictory" to her Renaissance Fancies and Studies (1895), Lee celebrates Pater's moral evolution, stating, "he began as an aesthete, and ended as a moralist." Her own thinking is frequently described as undergoing a similar transformation, but it might be even more accurate to say that Lee ended as an ethical aesthete, as a moral hedonist. She finally manages to integrate Ruskinian ethics and Paterian pleasure, allowing her to argue in Laurus Nobilis (1909) that "art can teach us to seek our pleasure without injuring others. " ${ }^{20}$ In her fiction of the late nineteenth century and her aesthetic theory of the early twentieth, she insists that the finest, most intense pleasure actually arises from ethical interactions, from interactions in which the subject attends to the otherness of the object and engages in behavior that leads to the loss of mastery, dominance, and control on the part of the subject. It is only by being as ethical as Ruskin wished us to be, Lee argues, that we may experience the excessive aesthetic pleasure that Pater described. ${ }^{21}$

In developing a method of consumption that engages with modern theories of aesthetic pleasure and desire while preserving what was redemptive and ethical in previous theories of appreciation, Lee learns from the example of lateVictorian economic theorists, such as Alfred Marshall, whose work informs her concern with moral consumer behavior. In the late 1880s, Lee gave herself a crash 
course in economics. The Vernon Lee Library at the British Institute in Florence contains numerous works of economic theory, such as Henry Sidgwick's Principles of Political Economy (1883), that Lee read and heavily annotated during the 1880s. In her 1887-1888 commonplace book, Lee notes that she read John Stuart Mill's Principles of Political Economy and reread Alfred Marshall's Economics of Industry (1879). ${ }^{22}$ During this period she was particularly drawn to economic theorists, like Marshall, who resisted what Regenia Gagnier refers to as the "normative evisceration" of economics, the hegemonic shift that occurred in the late nineteenth century that involved the replacement of a concern with social relations and production with a theory of the individual consumer and his wants. ${ }^{23}$ As Lee engages with the most recent strains of aesthetic thinking while seeking to remedy the elision of ethics in modern consumer practices, she exhibits an interest in economic theorists who engage with the most recent developments in economic thought yet resist the erasure of ethics in marginal utility theory.

Alfred Marshall is commonly acknowledged as the moral mediator of neoclassical economic theory. ${ }^{24}$ Though he was largely responsible for acquainting Victorian England with marginal utility theory, he always remained somewhat wary of Jevons's theories. J. K. Whitaker has attempted to account for this wariness by drawing attention to his early studies in philosophy and psychology, arguing that Marshall, more than most economists, understood his subject in terms of its wider ethical ramifications, and recognized Jevons's "utilitarian calculus of individual decision" as psychologically narrow and naive. ${ }^{25}$ Marshall did not wish to reject marginal utility theory, but he was leery of Jevons's disregard for ethics. His assertion that one can and should consume in an ethical manner is a direct contradiction of Jevons's insistence that consumer choice cannot be considered in moral terms, and he typically attempts to flesh out Jevons's narrow "hedonistic calculus" by considering phenomena such as charity, duty, and chivalry.

Reading Economics of Industry not once, but twice, Lee would have presumably been struck by one of the most pronounced elements of Marshall's ethical thinking: his desire to make moral distinctions between types of consumption. Though Jevons argues that consumer choice should not be considered a moral category, Marshall insists that "the better kinds of consumer goods were not those which simply satisfied man's existing wants, but those which actually contributed to the 'development of his activities, physical, mental, and moral." 26 For example, in Economics of Industry he celebrates the acquisition of "good" art and "artistic" fashion, for these modes of consumption contribute to the "well-being of the nation." ${ }^{27}$ According to Marshall, the way one consumes is a reflection of one's moral constitution. He treats "lavish expenditure" and "intemperate habits" as an indication of a "selfish disposition that cares above all for its own enjoyments," and asserts that temperance "increases a man's power, and generally increases his will to save for the benefit for his children, and also to bring them 
up well, and invest personal capital in them" (38). Marshall was a firm believer in social evolution, and he believed that the social improvement that accompanied economic progress would also foster better consumption patterns. As David Reisman notes, this optimistic belief in the emergence of finer and more moral manners of consuming is evident in his later works, such as Principles of Economics, in which he celebrates the popularity of tea, as opposed to alcohol, as evidence of social evolution. This concept was rehearsed earlier in Economics of Industry, where he states hopefully, "A time may come when it will be thought absurd for a woman to display her wealth by carrying about a great quantity of expensive materials and embroidery; just as a painter who advertised the price he had paid for the paints on his picture would be thought vulgar" (17-18).

While Lee may have shared Marshall's belief that consumption could be enacted in an ethical manner and that the way one consumed could serve to tell much about one's moral nature, as her essay on Taine indicates, she was not as optimistic about the natural evolution of proper methods of appreciating. Lee frequently represented the fin de siècle as a moment of cultural crisis marked by frivolity and wasteful acquisition, and she tends to associate ethical consumption with a previous or lost simplicity. In her works, amelioratory consumption is often posited as the natural domain of the rural, "common" folk of the past, who, for example, "corrected" and transformed the "cast-off" poetry of the Provençal and Sicilian schools during the fourteenth century. As they repeated, altered, and adapted these poems, they infused them with their own "freshness" and "straightforwardness," "until this cast-off poetic apparel, stretched on the freer moral limbs of the natural folk, faded and stained by weather and earth into new and richer tints, had lost all its original fashionable stiffness, ... and had acquired instead I know not what grace of unexpectedness, picturesqueness, and ease." 28 The modern, urban, "refined" individual lacks the "freer moral limbs of the natural folk," and thus does not engage in this beneficial mode of consumption naturally or instinctually. In Laurus Nobilis Lee argues that in the past "even the most everyday persons" had a great "appreciative sensibility" that came to them "through daily habit of artistic forms which existed and varied in the commonest objects just as in the greatest masterpieces." By contrast, "us moderns" have no access to this instinctual reflex to "respond to the work of art's bidding" (169). The modern consumer has been desensitized to art, and rather than obeying the work, the modern consumer bends the art object to his or her bidding. Lee takes it upon herself to instruct the fin-de-siècle consumer, modeling moral types of appreciation (like the kind and correct assimilation performed by the "common folk" of the Renaissance) that honor rather than deplete or degrade the object in question.

History is essential to Lee's initial formulation of this moral education of the modern consumer. In her supernatural fiction Lee models a method of relating to objects that is at once more ethical and more pleasurable than those object relations, such as collecting, that involve ignoring historical contexts. Considering 
objects historically allows Lee to remedy the problematic erasure of contexts of origin in modern consumer practices and to reconcile ethics and pleasure. Attending to the historical otherness of an object, acknowledging its separateness and sovereignty, endows the object in question with an awe-inspiring distance and difference. The consuming subject is momentarily overcome with shock and pleasure as he or she makes contact with something truly other than and separate from the self. When the heroic historicists in Lee's ghost stories come into the presence of the past, they experience intense aesthetic pleasure that is a direct result of their ethical behavior, of making themselves vulnerable to difference. Historicized consumption facilitates a moral brand of hedonism.

Anxieties about modern temporality register heavily in Lee's fiction. Her works reflect and react to a historical moment when economic and cultural developments have seemingly quickened the passing of time. Ronald Schleifer argues that this moment, the advent of the second industrial revolution, "is precisely when . . the possibility of forgetting time and temporality . . is lost. ${ }^{29}$ In his examination of the development of a "temporally-bound crisisconsciousness" in the late nineteenth century, he asserts that the crisis of abundance initiated by the second industrial revolution contributed to a transformation in temporal understanding in which the homogenous time associated with ideologies of progress was replaced by a heterogeneous, constellated, panicridden temporal sensibility, creating feelings of dislocation, discontinuity, and bewilderment. Time becomes threatening that cannot be ignored. However, as works on modern temporality, by Peter Osborne and Richard Terdiman, for example, have emphasized, in its emphasis on the new and the speed with which things alter, modernity guarantees that while time cannot be forgotten, the past can. ${ }^{30}$ Terdiman's argument stresses the extent to which "under capitalism, the traces of history, of process, of time, disappear from the forms of bourgeois thought. ${ }^{31}$ Modernity, then, may be described as marked by a split sense of temporality. Time as something that is happening seems omnipresent and overwhelming, while time as something that has happened is veiled from memory.

Late-Victorian economic theory, with its emphasis on insatiability and the incessant quest for new objects of desire, reflects the double nature of time in modernity. Concentrating on the consumer's insatiable desire for the new foregrounds the quickened nature of time in consumer culture, while the disregard for contexts of origin in neoclassical economic theory veils and suppresses the background of commodities. Regenia Gagnier flags the elision of history as one of the most troubling elements of neoclassical economic theory. Economic theory after the marginal revolution, in its emphasis on consumer desire as a determinant of value, disregards the history of a commodity, the labor that produced it. Referring to Menger's statement that "no one in practical life asks for the history of the origin of a good in estimating its value," Gagnier states that Menger's insistence that "no one cares about the investment of labor makes the care that 
pervades Smith, Mill, and Marx's political economy retrospectively prominent." 32 The disregard for contexts of origin and conditions of production in neoclassical economic theory was a central element of the normative evisceration of economic thought described by Gagnier.

The economic and aesthetic theorists to which Lee was drawn in the late nineteenth century seemed to be in agreement that something troubling was happening to the sense of the past, that the shifts occurring in turn-of-the-century culture were contributing to a loss of history. Much as she was drawn to theorists who insisted on preserving an ethical component in economic thought, Lee also seems to have been interested in economic thinkers, such as Henry Sidgwick, who contested the elision of production in neoclassical economics. This is not to say that Lee wished to move nostalgically backward from the emphasis on consumption in late-Victorian economic theory. In fact, her marginalia in her copy of Karl Marx's Capital indicate that she found Marx's overwhelming emphasis on labor and his neglect of supply and demand exasperating. ${ }^{33}$ She is instead interested in theorists, like Sidgwick, who grapple with the recent shift in economic thinking and endeavor to preserve a space for considerations of the past, of labor and contexts of origin, in late-nineteenth-century economic theory.

Historians of economic thought frequently question the extent to which the marginal revolution was in fact a revolution, or argue that the effects of this revolution were not evident until long after the revolutionary treatises of Jevons, Walras, and Menger were published. ${ }^{34}$ However, though Mark Blaug describes Sidgwick's Principles of Political Economy (1883) as "entirely cast in the old mold," there is no question that Sidgwick understood the appearance of Jevons's Theory of Political Economy to be an event of tremendous significance for the discipline of economics. In the introduction to his Principles Sidgwick outlines "the present state of economic controversy in England," asserting that "some thirty-five years ago, both the Theory of Political Economy in its main outlines, and the most important practical applications of it, were considered as finally settled by the great majority of educated persons in England." ${ }^{35}$ However, by 1871 "these halcyon days of Political Economy had passed away," and one of the foremost reasons for their termination, according to Sidgwick, was the "shock ... given in 1871 by the publication of Jevons's Theory of Political Economy" $(4,5)$.

Though Sidgwick refers to Jevons's text as "the most important contribution to economic theory that had been made in England for a generation," he explicitly states that both the form and the content of his Principles will challenge Jevons's overwhelming emphasis on the individual consumer. The central tenet of Jevons's theory is that "value depends entirely on utility," and utility is defined as the pleasure the commodity produces in a consumer. ${ }^{36}$ Labor, according to Jevons, cannot be regarded as the source of value, for the labor spent on the production of a commodity is "gone and lost for ever." 37 Sidgwick "quite [agrees] with Jevons as to the fundamental importance of certain propositions relating to Consumption." 
Nevertheless, he decides "to introduce [propositions concerning the topic of consumption] in discussing the questions relating to Production, Distribution, and Exchange which they help to elucidate" (4). He integrates his discussion of consumer demand into chapters on "The Definition and Measure of Value" and "Theory of Exchange Value of Material Products," and devotes attention to the role of labor and the cost of production as well as consumer demand in the determination of value. Sidgwick refuses to engage in Jevons's erasure of production in his consideration of the value of material products and insists on the "dependence of Value on Cost of Production and Demand together" (205).

Sidgwick's economic primer would have alerted Lee to the fact that a major transition was occurring in the discipline of economics, that this transition was related to a new concern with consumption, and that this transition was being contested by economic theorists, like Sidgwick, who insisted that consumption must be considered in relation to production. The elision of production in post1870s economic theory is mirrored in the erasure of labor in late-Victorian consumer practices, such as the collecting craze, that replace narratives of production with an emphasis on individual taste. Collecting, the ultimate practical manifestation of the consumerist ideology articulated by Jevons, may be understood as a symptom of the cultural climate that produced the marginal revolution. Susan Stewart's discussion of collection reveals why the practice of collecting may have become increasingly widespread during the same historical period that produced the marginal revolution: "In its erasure of labor, the collection is prelapsarian. One 'finds' the elements of the collection much as the prelapsarian Adam and Eve could find the satisfaction of their needs without a necessary articulation of desire. The collector constructs a narrative of luck which replaces the narrative of production. Thus the collection is not only far removed from contexts of material production; it is also the most abstract of all forms of consumption." 38 Sidgwick's insistence on the relevance of production is an explicit response to Jevons's elision of labor, but it may also function as an implicit corrective to the erasure of labor contexts of origin in modern consumer practices such as collecting. Sidgwick's effort to respond to the elision of production in modern theories of value is the economic equivalent of Lee's attempt to reinstate reverence for historical otherness in modern modes of aesthetic appreciation. The erasure of conditions of production in consumer culture ensures that taste replaces the historical and the social. The less a customer understands about the historical and social situation that produced a product, the more the customer's individual, subjective response becomes important. Sidgwick's Principles and Lee's Hauntings express wariness about developments within the realms of economics and aesthetics that ascribe an increasing amount of significance to the subject's desires while disregarding other determinants of an object's meaning or value.

The fact that Lee's response to modern consumer practices relies so heavily upon the consideration of history places her firmly within a Ruskinian frame- 
work. As he works to battle market society's degenerative effects on the aesthetic realm, Ruskin returns repeatedly to the centrality of history. In his Manchester lectures, for example, he exhorts his audience to "act more for preservation and less for production" and suggests that the Victorian public's thirst for new things is encouraging the production of bad things, stating, "Here in England, we are making enormous and expensive efforts to produce new art of all kinds, knowing all the while that the greater part of it is bad." 39 "All that is desirable to be done in this matter," he argues, "is merely to take pride in preserving great art, instead of in producing mean art" (108). Ruskin's plan for the preservation of an embattled aesthetic realm hinges upon the ability of consumers to love and understand the beautiful works of the past. According to Ruskin's formulation, the fetishization of novelty, which undermines the possibility of historically minded aesthetics, contributes to a degeneration of consumer desire, which in turn produces a market for inferior aesthetic production. As Ruskin informed his listeners in Manchester, "The very fact that we despise the great art of the past shows that we cannot produce great art now" (123). Lee inherited Ruskin's sincere belief in the redemptive potential of historically minded art appreciation.

Pater's historical spectatorship, which emerged from his critique of dislocated or amnesiac modern temporality, presumably served as another important model for Lee's historically minded response to consumer culture. ${ }^{40}$ Paterian spectatorship is a mode of consumption that actively responds to the double nature of time in modernity. While the rhetoric of "grasping at any exquisite passion" in "intervals" of "brevity" in Pater's "Conclusion" might seem to reproduce the disconnected temporality of consumer culture, it is importantly the consideration of works of art and moments in history that allows Pater to "court new impressions." The aesthetic heroes of Pater's prose are, like himself, aesthetic spectators and scholarly consumers, and the acts of consumption in which they engage are privileged as productive and regenerative solutions to the temporal crisis in modernity. Marius the Epicurean's vocation, "insight through culture," interpretation of "the various forms of ancient art and thought," is what allows him "to create, to live perhaps a little while beyond the allotted hours." ${ }^{41}$ Marius's productive appreciation is a result of "his longing ... for something to hold by amid the "perpetual flux," for something to free him from amnesiac temporality. ${ }^{42}$ The description of Marius's existence in "reminiscence" elucidates the fundamental difference between Pater's aesthetic philosophy of "grasping at any exquisite passion" in "intervals" of "brevity" and the dislocated temporality of modernity:

Amid his eager grasping at the sensation, the consciousness, of the present, he had come to see that, after all the main point of economy in the conduct of the present, was the question-How will it look to me, at what shall I value it, this day next year? - that in any given day or month one's main concern was its impression for the memory. A strange trick 
memory sometimes played him; for with no natural gradation, what was of last month, or of yesterday, of to-day even, would seem far off, as entirely detached from him, as things of ten years ago. Detached from him, yet very real, there lay certain spaces of his life, in delicate perspective, under a favourable light; and somehow all the less fortunate detail and circumstance had parted from them. Such hours were oftenest those in which he had been helped by work of others to the pleasurable apprehension of art, of nature, of life. ${ }^{43}$

The "economy" of Marius's existence relies upon "grasping at sensations" that will be preserved in memory. As a response to what Terdiman describes as the memory crisis in modernity, the marking of moments by a spectatorship that is informed by cultural insight, by great works of the past and the responses they evoke, represents a practice of perception that reinstates memory and maintains history. "Pleasurable apprehension" of the material world, of art from the past, and the beauty toward which it directs its audience emerge as methods for creating links between dislocated modern moments.

Unlike Lee's mode of ethical consumption, Paterian spectatorship first and foremost serves the desires of the perceiving subject, bringing security, knowledge, or increased self-understanding. For example, Duke Carl of Rosenmold, one of Pater's heroic spectators of history, believes that the apprehension of the "historic soul" of past ages will lead to "a deeper understanding of the past, of nature, of one's self." +4 Johann Winckelmann endeavors to "bring down that [Hellenic] ideal into the gaudy perplexed light of modern life," to create a site of solace within the confines of modernity. ${ }^{45}$ And Marius's pleasurable apprehension brings comfort in the face of Heraclitean flux. ${ }^{+6}$ The subjectivism of Paterian spectatorship denigrates the perceived object to its use value, apprehending it in terms of how it may benefit the subject.

Lee shared Pater's belief that consumption can be a productive act and one that responds to the elision of history in consumer culture. However, there is a marked difference between the privileging of perceiving subjects in Pater's method of historically minded appreciation and the sensitivity to the separate life of objects evident in the majority of Lee's works. Lee's first collection of supernatural fiction, Hauntings (1890), expresses her distress about the effects of modern modes of consumption on the art object. In her ghost stories, she articulates a critique of subjectivist forms of aesthetic interaction while at the same time modeling a method of proper appreciation that might serve as a corrective to the tendency toward aggressive subjectivism in consumer culture. Drawing on Walter Benjamin, I refer to this practice as "re-auraticization," a mode of ethical consumption that reinvigorates degraded objects by attending to their histories. In Hauntings Lee morally mediates aestheticist hedonism, basing pleasure on the acknowledgment of difference. 


\section{Hauntings: Coming into the Presence of the Past}

Supernatural experiences stand in Lee's work for those thrilling moments when one truly sees and engages with alterity. As Angela Leighton has recently noted, Lee's ghosts "figure, not the terror of the unknown, but the seductive, fascinating difference of the past." ${ }^{47}$ In Lee's ghost stories, acknowledging the historical otherness of an object reendows that object with aura, with the capacity to instill destabilizing effects and the ability to return the gaze to which Benjamin refers in his Baudelaire essay. ${ }^{48}$ Miriam Hansen argues that an antimony exists in Benjamin's consideration of the aura of the artwork in modernity. What Hansen calls Position A, developed in "The Work of Art in the Age of Mechanical Reproduction," "turns [its] back on the decaying 'aura,' which cannot be salvaged anyway" and "welcomes the technical media . . . because they promote the 'liquidation' of the cultural heritage, of bourgeois-humanist notions of art." What Hansen refers to as Position B, articulated in Benjamin's essays on Charles Baudelaire, Marcel Proust, and Nikolai Leskov, "laments the decline of experience, synonymous with 'the disintegration of the aura in the experience of shock'" and mourns the decline of "the peculiar structure of auratic experience, that of investing the phenomenon we experience with the ability to return the gaze, a potentially destabilizing encounter with otherness." 49 Lee's critique of the degradation of the art object in market society is marked by a sense of loss similar to what Hansen refers to as Benjamin's Position B, but Lee additionally maintains the hope that this lamentable loss of aura may be rectified.

The stories of heroic historicists in Hauntings respond to the predominance of what Susan Stewart refers to as the "aesthetics of mercantilism" in consumer culture, the extraction of objects from their contexts, which places them within "the play of signifiers that characterizes an exchange economy." historically informed appreciation of culture that Lee develops in these stories attempts to remedy what Remy Saisselin calls the "bibelotization of art," the transformation of works of art, "first perceived as aesthetic [objects] and historical [signs]," into bibelots whose history and aura have been eliminated. ${ }^{51}$ Lee calls upon the established conventions of gothic and supernatural fiction, which rely upon the thrilling idea of the intrusion of the past into the present, to speak to the attractiveness of this possibility at a moment when the past seems to be disappearing all too quickly. The stories in Hauntings are populated with objects that have been degraded, decontextualized, or reproduced for the shopping needs of tourists: the portrait carelessly cast aside into the closet of an institutional collection in "Amour Dure;" the "profaned clothes of the dead" worn in a vulgar masquerade in "Oke of Okehurst;" the penny prints of portraits sold in the square in the "modern bric-a-brac shop Venice of tourists" in "A Wicked Voice." 52 However, in each of these stories, a character is drawn to a particular cultural relic because of his or her knowledge of its historical origin, allowing the object to 
emerge from the past to terrorize the present. In Lee's ghost fiction, historicized consumption retrieves the art object from degradation, from the elision of historical otherness that has rendered the object an innocuous and "pleasant plaything," and reendows it with aura to the point where the art object's capacity to shock and destabilize, to return the gaze, has become truly dangerous. ${ }^{53}$

Spiridion Trepka's encounter with the ghost of a Renaissance femme fatale in "Amour Dure" may be read as a representative narrative of historicized consumption. Trepka is a historian visiting the archives in Urbania, Italy, and his curiosity about the past is riddled with anxieties concerning the possibility of authentic historical knowledge, with whether it is "folly" or "falsehood" to imagine that one "canst ever come in spirit into the presence of the Past." ${ }^{4}$ Lodging in the house of a dealer in antiquities, surrounded by a chaotic collection of "old carved chairs, sofas of the Empire, [and] embossed and gilded wedding-chests," spending his free time with the vice prefect's son, "an amiable young man with a languid interest in Urbanian history and archaeology, of which he is profoundly ignorant," Trepka is surrounded by history and its relics rendered inane and banal $(7,20)$. However, he retains his hope for an authentic interaction with the past, and this hope is from the first mingled with the attraction he feels for "the strange figure of a woman, which appeared out of the dry pages of Gualterio's and Padre de Sanctis's histories of this place" (8). Medea da Carpi, a femme fatale of the sixteenth century who destroyed five men, becomes an obsession for Trepka, and he begins hunting for portraits of her, which he spends hours poring over, "wondering what this face, which led so many to their death, may have been like when it spoke or smiled" (18).

The intensity of Trepka's curiosity about Medea da Carpi facilitates an interaction with an art object that answers and then exceeds his desire for authentic contact with the past. Wandering about the archives, he stumbles into a closet and gazes into a mirror in which he sees reflected a portrait of Medea da Carpi. While Trepka's longing for Medea may have once threatened to transform her into nothing more than an object of erotic desire, the intensely violent and agitated aesthetic response the portrait evokes in him restores power to the femme fatale and to the work of art itself. Trepka's very "being" is "shaken" by the encounter, and as a seeming consequence his vision has been refined, his awareness sharpened:

I approached, and looking at the frame, looked also, mechanically, into the glass. I gave a great start, and almost shrieked, I do believe ... Behind my own image stood another, a figure close to my shoulder, a face close to mine; and that figure, that face, hers! Medea da Carpi's! I turned sharp round, as white, I think as the ghost I expected to see. On the wall opposite the mirror, just a pace or two behind where I had been standing, hung a portrait. And such a portrait! — Bronzio never painted a grander 
one. Against a background of harsh, dark blue, there stands a figure of the Duchess (for it is Medea, the real Medea, a thousand times more real, individual, and powerful than in the other portraits), seated stiffly in a high-backed chair, sustained, as it were, almost rigid, by the stiff brocade of skirts and stomacher, stiffer for plaques of embroidered silver flowers and rows of seed pearl. The dress is, with its mixture of silver and pearl, of a strange dull red, a wicked poppy-juice colour, against which the flesh of the long, narrow hands with fringe-like fingers; of the long slender neck, and the face with bared forehead, looks white and hard, like alabaster. The face is the same as in the other portraits . . but with a purity of line, a dazzling splendour of skin, and intensity of look immeasurably superior to all the other portraits ... I still, after several hours, feel terribly shaken in all my being. (32-33)

Despite (or perhaps because of) his agitation, Trepka is able to perceive each and every fine detail of the portrait-the harshness of the blues, the strangeness of the "wicked" reds, the white like alabaster, the purity of line. He is excessively aware of the appearance of the portrait, of its story, of the fear and delight it has inspired in him. Understanding the painting as a distant, historically other object has allowed him to see the painting itself in a finer way. Trepka's mode of historicized consumption has "catalyzed but cannot contain" a destabilizing encounter with a work of art and resurrected and recontextualized an object that had been cast aside into the closet of an institutional collection.

Immediately following his encounter with the portrait, Medea da Carpi begins to haunt Trepka, appearing to him beneath his window, writing him letters, convincing him to avenge her murder, and finally murdering him. The haunting of Spiridion Trepka by the ghost of a Renaissance beauty is an allegorical representation of historicized consumption, its capacity to reendow the artwork with aura and liberate the perceived object from the demands and desires of the perceiving subject. Spiridion's reverence for the past, for the tale of Medea, for the Renaissance, the historical moment that spawned her incredible cruelty, renders him vulnerable to each and every detail of the grand portrait of his historical beloved. This sensitivity to the beauty of the artwork initiates an extended supernatural encounter that figures the excessive, unsettling pleasure facilitated by ethical interactions with otherness. Medea's ghost has often been understood as a fantasy about feminine revenge, as the personification of male hysteria and anxiety concerning the limitations of patriarchal historiography or as "a cipher, a problematic projection of male desire." 55 Lee frequently uses objectified femininity to signify wrong ways of looking, to critique aggressive or unethical methods of perception that privilege the desiring subject. Spiridion's initial eroticized longing for Medea reinforces "conventional (male) historiography." ${ }^{56}$ However, his hunger for an authentic interaction with the past opens him up to a "destabilizing 
encounter with otherness," which fleshes out a misrepresented female historical figure and reendows a degraded art object with auratic capacity. ${ }^{57}$ Spiridion's murder is not a punishment but a figure for what it might mean to allow oneself to be troubled, transformed, or unsettled by an aesthetic experience. This method of appreciating is juxtaposed with and implicitly privileged over the antiquity dealer's and the vice prefect's mundane, safe manner of perception, which allows artworks to be understood as "pleasant playthings" and history to be treated as a banality.

Figures like the antiquity dealer and the vice prefect's son serve repeatedly in Lee's fiction as foils to ethical consumers whose manner of appreciation can resurrect degraded objects. Collectors in particular are satirized and vilified. Collecting - a practice in which the way we read objects and the way we buy converge and are very much foregrounded-operates as a convenient site for articulating a more generalized critique of modern methods of consumption. Lee's critique of collecting focuses on the isolation of objects from their functions or historical contexts, the replacement of the historical and the social with an emphasis on individual taste. As Jean Baudrillard argues, "Although the collection may speak to other people, it is always first and foremost a discourse directed toward oneself." ${ }^{8}$ When the object is "divested of its function" and "abstracted from any practical context," it "takes on a strictly subjective status." 59 In Laurus Nobilis Lee speaks explicitly about her distaste for the practice of collecting. She carefully distinguishes proper methods of approaching art objects from ownership, stating that "real aesthetic keenness ... means appreciating beauty, not collecting beautiful properties." Lee associates this "aesthetic keenness" with reverence and opposes it to "vanity," the reverence for the self that motivates the act of collecting. ${ }^{60}$ Lee argues that the vanity of the collector actually interferes with the appreciation of the owned objects:

'Tis like the tension of a muscle, this constant keeping the consciousness aware by repeating "Mine-mine-mine and not theirs; not theirs, but mine." And this wearisome act of self-assertion leaves little power for appreciation, for the appreciation which others can have quite equally, and without which there is no reality at all in ownership. Hence, the deeper our enjoyment of beauty, the freer shall we become of the dreadful delusion of exclusive appropriation, despising such unreal possession in proportion as we have tasted the real one. (57)

The collector's fixation on the "idea of self" intrudes upon his every encounter with his collection, veiling the beauty of the collected objects from him, desensitizing him to their difference. This highly critical assessment of collectors' relationship to objects is reiterated in Lee's fiction. The critique of collecting articulated in the fiction serves to reinforce the critique of conventional modes of consumption implicit in her praxis of historicized consumption. Her treatment 
of collecting implies that the aggressive dominance of objects negates the possibility of transformative encounters with otherness.

The collecting impulse of Maestro Fa Diesis in "Winthrop's Adventure" (1881) is represented as a grotesque and consuming sickness that absorbs and emaciates the world surrounding it while nourishing the selfhood of the collector:

[Fa Diesis] possessed very fine collections of things musical, a perfect museum. He had a handsome old palace, which was literally tumbling to pieces, and of which the whole floor was taken up by his collections. His old MSS., his precious missals, his papyri, his autographs, his blackletter books, his prints and pictures, his innumerable ivory inlaid harpsichords and ebony fretted lutes and viols, lived in fine, spacious rooms, with carven oak ceilings and painted window frames, while he lived in some miserable little garret to the back, on what I can't say, but I should judge, by the spectral appearance of his old woman servant and a halfimbecile boy who served him, on nothing more substantial than bean husks and warm water. They seemed to suffer from this diet; but I suspect that their master must have absorbed some mysterious vivifying fluid from his MSS. and old instruments, for he seemed to be made of steel, and was the most provokingly active little fellow, keeping one's nerves in perpetual irritation by his friskiness and volubility. He cared for nothing in the wide world save his collections; he had cut down tree after tree, he had sold field after field and farm after farm; he had sold his furniture, his tapestries, his plate, his family papers, his own clothes. He would have taken the tiles off his roof and the glass out of his windows to buy some score of the sixteenth century, some illuminated mass book or some Cremonese fiddle. ${ }^{61}$

Fa Diesis's desire is troubling because it saps the surrounding area, desiccates the space it resides within, and even denies sustenance to those who serve it. The collector, however, derives "some mysterious vivifying fluid" from owning these objects, from his severance of the objects not only from their history but from their function as well, so that they can do nothing but be his (or be him). Though Fa Diesis's collection contains all "things musical," "for music itself . . . he cared not a jot, and regarded it as useful only insomuch as it had produced the objects of his passion, the things which he could spend all his life in dusting, labeling, counting, and cataloguing, for not a chord, not a note was ever heard in his house" (156). The mysterious vivifying fluid that Fa Diesis obtains from his "things musical" is a result of their complete separation from their contexts and their functions. No longer utilized, they are simply possessed, and as possessions they can only refer back to the collector who owns and dominates them. Though Fa Diesis may seem to adore and even respect these objects, they are ordered, catalogued, and silenced, and in fact exist solely to define and satisfy the taste of the subject to whom they belong. 
Fa Diesis is opposed within the tale to Julian Winthrop, an ethical consumer whose historicized consumption of a painting results in a destabilizing encounter comparable in its pleasure and its terror to the haunting of Spiridion Trepka. Winthrop's capacity for authentic reverence for the otherness of objects becomes evident when he engages in a fantasy of rebellion in which all the objects in Fa Diesis's collection are reunited with their functions and aggressively assert their independent existences. He dreams that "as soon as the master had drawn his bolts and gone off to bed, all the slumbering music would awake," "the kettledrums and tamtams would strike up, the organ tubes would suddenly be filled with sound, the old gilded harpsichords would jingle like fury" (157). Winthrop actually assists in the rebellion of one of Fa Diesis's belongings by reuniting this object with its historical context. In a lumber room in Fa Diesis's home, where the collector stores "time-stained portraits in corslets and bobwigs, the senatorial ancestors of Fa Diesis, who had had to make room for the bookshelves and instrument-cases filling the room," Winthrop comes across a portrait of an eighteenth-century singer (159). He resurrects this degraded casualty of Fa Diesis's obsession, allowing the strange picture to "haunt" him, piecing together the story of the singer's life, and returning to the house where he was murdered. There Winthrop comes face to face with "the deep, soft, yearning eyes of the portrait at Fa Diesis's," hears his "strange exquisite voice," which "seemed to steep the soul in enervating bliss" during a supernatural private concert, a moment of "numbing terror" and aesthetic excess $(198,197,196)$. Winthrop's manner of perception reinvigorates a silenced and discarded object, allowing it to speak to, terrify, and overwhelm the perceiving subject. ${ }^{62}$

Lee's optimistic belief that the aura of the artwork may be salvaged, a contradiction of the argument articulated in Benjamin's artwork essay, may simply be a symptom of the fact that she is considering the impact of modernity on the artwork at an earlier period, and therefore her understanding of the implications of modernity is somehow naïve or incomplete. However, her ghost stories repeatedly insist that certain modes of aesthetic consumption may re-create the structure of auratic experience and endow the artwork with the capacity to return the gaze, that the degradation of the artwork in modernity is not final or complete, and that we may choose to interact with the work of art in a manner that allows for a destabilizing encounter with historical otherness.

\section{Conclusion}

The notion of historicized consumption developed in Lee's supernatural fiction serves as an important foundation for her later thinking on aesthetics and altruism, for her belief that the finest and the most intense pleasure arises from ethical interactions. Even in The Beautiful (1913), a work Lee described as nonnormative, as concerned with "is" rather than "ought," Lee exhibits consid- 
eration for the alterity of objects, refusing to view them in terms of their utility. ${ }^{63}$ She opposes the "aesthetic" manner of perceiving the beautiful to practical or scientific perception, perception that is guided by a "looming, dominating goal, an ultimate desired result" (13). In order to demonstrate the difference among these manners of seeing, she describes the responses of three imaginary wayfarers to a view. While the practical man considers the benefits of starting a joint stock company to build a tram and funicular at the spot ("It might prove a godsend and a capital investment, though I suppose some people would say it spoilt the view") and the scientific man ponders what sort of knowledge he might garner by studying the area ("It would be interesting to examine whether the summits have been ground down in places by ice, and whether there are traces of volcanic action at different geological epochs"), the aesthetic man is "satisfied with the wonderfully harmonized scheme of light and colour, the pattern (more and more detailed, more and more co-ordinated with every additional exploring glance) of keenly thrusting, delicately yielding lines" $(9,15)$. The aesthetic man's appreciation of the view illustrates Lee's definition of the beautiful: "an attitude of preference, but not an attitude of present or future turning to our purposes" (4; italics in original). This unpractical attitude is not synonymous with Frederich Schiller and Herbert Spencer's equation of aesthetic enjoyment with play, for the former differs from the latter by its "contemplative nature." Play, Lee argues, requires concentration on goals and moves, "an eminently practical state of mind, one diametrically opposed to contemplation" (7). Aesthetic contemplation means to think into, rather than away from, the object perceived, to consider "aspects" rather than "things." While a "thing" is the set of memories, thoughts, and expectations we associate with an object that we recognize, an aspect has more to do with the way objects really look, with the shapes they are composed of, the colors, the materials. Once we begin "thinking away from the shapes" so that we may have practical thoughts about an object, we are thinking in terms of things rather than aspects, and we are no longer in the presence of the beautiful (133).

Lee acknowledges that her idea of the beautiful has much to do with pleasure and that the unpractical aesthetic attitude she describes is not the same as disinterestedness, for "aesthetic appreciation implies enjoyment and is so far the very reverse of disinterestedness" (6). However, the pleasure involved does not contribute to the security and stability of the perceiving subject. Her theory of empathy, of the way our minds and bodies "feel into" the objects we examine, involves "the merging of the perceptive activities of the subject in the qualities of the object of perception" (57). She states very clearly that empathy is not a projection of the ego into the object or shape under observation. In fact, feeling into an object "depends upon a comparative or momentary abeyance of all thought of an ego" (67). As Hilary Fraser notes, Lee's aesthetics of empathy possesses many of the same qualities Anne Mellor associates with feminine Romanticism, "a self that is fluid, absorptive, responsive, with permeable ego boundaries." ${ }^{64}$ Her aesthetics of 
empathy effectively involves the same sort of destabilizing encounter with otherness that historicized consumption facilitates, and the pleasure she associates with aesthetic perception in both her aesthetic theory and her ghost stories is a pleasure that unsettles, alters, or transforms the perceiving subject.

It is Bill Brown's argument that "things" emerge as a major preoccupation in the work of artists and theorists such as Ezra Pound, Marcel Duchamp, William Carlos Williams, Gertrude Stein, Virginia Woolf, Georg Lukács, Martin Heidegger, and Walter Benjamin following the onset of the First World War. His argument is historically specific and considers the impact of a culture of scarcity in war-traumatized Europe on the development of alternative economies of or passions for materials. However, his theory of the "thing" is also useful for considering the situation of the object in the culture of abundance that followed the second industrial revolution. Brown draws heavily from Georg Simmel, who argued that within a culture of abundance "increased access to things ... results in a loss of the thingness of things," and Brown's readings of modernist literature reveal "how various aesthetic practices work to compensate for that loss." ${ }^{65}$ Lee responds to the culture of abundance after the second industrial revolution and the "disappearance of the object" within that culture, and her praxis of historicized consumption compensates for the loss of contact with the alterity of things that is a consequence of modern consumerism. ${ }^{66}$ Brown's "thing" corresponds to what Lee refers to as an "aspect," and his discussion of the alternative economies that allow objects to become things echoes Lee's description of the "unpractical" nature of aesthetic perception, the moments when we think into aspects rather than away from them, preferring objects without turning them to our purposes. Brown argues that "we look through objects (to see what they disclose about history, society, culture, nature, or culture-above all what they disclose about us), but we only catch a glimpse of things. ${ }^{67}$ Paterian spectatorship relies on objects to operate as windows in exactly this manner. Brown's thing, "in contrast, can hardly function as a window. We begin to confront the thingness of objects when they stop working for us: when the drill breaks, when the car stalls, when the window gets filthy." ${ }^{\circ 8}$ Things are what is "excessive in objects, ... . what exceeds their mere materialization as objects or their mere utilization as objects-their force as a sensuous presence or as a metaphysical presence. ${ }^{169}$ We come into the presence of the thing when we are suddenly forced to truly look at an object, to pay attention to it, to see its "aspects."

Other nineteenth-century thinkers, such as William Wordsworth and John Ruskin, for example, critiqued faulty, inattentive, habitual vision and called their readers to look closely at the world around them. However, as George Leonard argues, in the process many of these same thinkers denigrated art objects to their use value, reduced them to aids that might help us learn how to see, to lenses through which we may see the world afresh. ${ }^{70}$ Lee's praxis of historicized consumption creates moments when art objects are no longer means to an end, when 
they rear up and assert their independence from instrumentalized relationships and do more than what the subject desired. However, she does not assign this capacity solely to art objects. As her aesthetic theory indicates, she was able to extend this treatment to landscapes, to furniture, and so forth. Her oeuvre as a whole is marked by an awareness of the otherness (or the "thingness") of objects.

Lee's sensitivity to the alterity of objects is a symptom of her more general concern with fostering ethical behavior. ${ }^{71}$ This concern is evident in her repudiation of the treatment of the poor in her ethical dialogues, her sensitivity to the suffering of animals in her writings on vivisection, her critique of the objectification of women in aestheticism, and her pacifism. ${ }^{72}$ In addition, her critique of modern methods of interacting with objects itself has broader ethical implications, for in questioning the privileging of the subject in consumer practices like collecting, she questions the sanctioning of appropriation and domination in consumer culture.

Lee is certainly not alone in her disapproval of the collector or in her critical relationship to consumerism. ${ }^{73}$ However, as I have argued here, many lateVictorian critiques of consumerism, modern temporality, or modern methods of perception reinforced the overwhelming privileging of the subject that is the foundation of consumerism. Gordon Bigelow's examination of mid-Victorian critiques of capitalism uncovers a similar phenomenon at work earlier in the century. He argues that "the defense of the market and the reaction against it in the mid-nineteenth century share the same fundamental assumptions." According to Bigelow, the romantic view of human subjectivity, which was developed in works that criticized the dehumanizing elements of existence in modern market society, served as the foundation for late-Victorian theories of capitalism based on the desires of the individual consumer. Lee's emphasis on the separateness of objects in her praxis of historicized consumption circumvents this tendency to privilege the subject. Bigelow suggests that "the seeming authenticity of consumer desire, the idea that purchasing is the clearest road toward personal expression, is still an unquestioned foundation of the late-capitalist marketplace, one where the romantic integrity of the perceiving subject is still presumed to be largely intact." ${ }^{74}$ Lee's attention to the degradation and decontextualization of objects involved in consumer practices like collecting illuminates the ethical implications of the exercise of taste, and her praxis of historicized consumption works to destabilize and unsettle the integrity of the perceiving subject.

When we posit the Victorians as passive victims of the rampant consumerism of their culture, we lose the opportunity to learn from their attempts to transform consuming into an ethical response to the problems of modernity and the market. Examining Lee's praxis of historicized consumption in relation to its aesthetic and economic sources indicates that the Victorians themselves may be understood as the source of twentieth- and twenty-first-century critiques of consumerism as well as practitioners of an ethical mode of consumption that implements this critique 
and actively responds to the nature of modernity. If the contemporary critique of modern consumerism does not take into account not only the Victorian origins of this critique but also the ways in which people involved in nineteenth-century consumer culture actively engaged with questions of history and ethics in an effort to reform consumption, then the critique itself is historically reductive. Similarly, narratives of the rise of mass markets, consumerism, and the commodification of art that castigate and reduce the act of consumption as entirely implicated within the logic of capitalism engage in a historically reductive analysis of the modern consumer. Vernon Lee maneuvered within the realities of modernity, consumerism, and the second industrial revolution and declared the necessity for a moral space within that reality, revealing that consumption can be much more than a destructive side effect of the workings of market society.

-Western Washington University

\section{Notes}

This essay benefited immensely from the comments and criticism of Kathy Psomiades. I am also indebted to Chris Vanden Bossche, Sara Maurer, Richard Dellamora, and the readers at Criticism for their invaluable feedback. I would also like to thank the librarians at Colby College's Special Collections Library and at the British Institute in Florence.

1. Vernon Lee, "The Doll," in For Maurice: Five Unlikely Stories (London: Bodely Head, 1927), 223.

2. Recent criticism of Vernon Lee, by Ruth Hoberman, for example, has attempted to position Lee as a formalist who disregards the historical context of the work of art ("In Quest of a Museal Aura: Turn of the Century Narratives about Museum-Displayed Objects," Victorian Literature and Culture 31, no. 2 [2003]: 467-82). In the introduction to Euphorion: Being Studies of the Antique and the Medieval in the Renaissance, Lee does acknowledge the futility of the quest for authentic historical knowledge, arguing that while "the sudden withdrawal ... of the curtain from before an altar-piece" may seem to "[bring] us face to face with real life of the Renaissance," in reality this sensation is "but a mere delusion, a deceit." Lee asserts that "we must never hope to evoke any spectres which can talk with us and we with them" from the Middle Ages or the Renaissance. Out of the distant past, she insists, "there come to us no familiars" (Euphorion: Being Studies of the Antique and the Medieval in the Renaissance [Boston: Robert Brothers, 1884], 20-22). However, in her works of supernatural fiction, Lee is highly preoccupied with the possibility that a particular method of perception may allow the past to manifest itself in the present. It is possible to resolve this seeming contradiction within Lee's approach to history through attention to her concern for objects in her supernatural fiction. Though, as Lee argues in Euphorion, it may be impossible to ever truly touch or know the past, the desire and the attempt to do so facilitates an interaction that is sensitive to the alterity of the object.

3. Peter Gurney examines the working-class cooperative movement and attempts to remedy the tendency to regard consumption as merely "a sordid and seductive sphere, nec- 
essarily generating new modes of 'false consciousness'" ( $C$ o-operative Culture and the Politics of Consumption in England, 1870-1930 [Manchester: Manchester University Press, 1996], 20). At the NAVSA conference in 2003, Deborah Cohen presented a paper titled "Material Good: The Victorians and Their Interiors" that examines the use of furniture to make moral statements in nineteenth-century interior decorating and argues for the coexistence of consumerism and moral concerns as well as the influence of religion on consumption. Carolyn Lesjak argues that Wilde theorizes a "new economy of pleasure based on ... the labors of hedonism," which suggests "how pleasure ... can-and must—be articulated within a left-wing project" ("Utopia, Use, and the Everyday: Oscar Wilde and a New Economy of Pleasure," English Literary History 67, no. 1 [2000]: 179, 181). Jennifer Wicke argues that "Woolfian modernism does not target publicity or consumption per se as problems-if anything ... the market is perceived to be a shadowy common room within which acts of much creative magic or transforming potential can be performed" ("Coterie Consumption: Bloomsbury, Keynes, and Modernism as Marketing," in Marketing Modernisms: Self-Promotion, Canonization, Rereading [Ann Arbor: University of Michigan Press, 1996], 129).

4. For a discussion of what Paul Delany refers to as the "ideology that consumption is intrinsically suspect," see his Literature, Money, and the Market: From Trollope to Amis (New York: Palgrave, 2002), 128. Lawrence Birken's assessment of the liberatory potential of consumption is one of the most significant recent attempts to cast this ideology into question. Birken argues that the transition to modern industrial capitalism provided the conditions for the emancipation of women and children as consumers. See Consuming Desire: Sexual Science and the Emergence of a Culture of Abundance, 1871-1914 (Ithaca, NY: Cornell University Press, 1988).

5. Jonah Siegel's recent discussion of the nineteenth-century culture of art (Desire and Excess: The Nineteenth-Century Culture of Art [Princeton, NJ: Princeton University Press, 2000]) offers an interesting counterpoint to discussions of the elision of history in modernity. Siegel argues that many nineteenth-century artists and critics were overwhelmed by a "disconcerting accumulation of antique matter" in modern museums and galleries, by a surfeit of history. However, the response to a seeming excess of history in the Victorian period described by Siegel is not fundamentally different from Lee's response to the erasure of history in modern consumer practices, such as collecting. As Siegel argues, what was troubling about the excess of history, for John Ruskin, for example, was the feeling that this excess was chaotic and disorganized. In a sense, then, the problem of too much history is similar to the problem of no history. The disorganized collection is an assemblage of historical objects in which historical order has been altogether neglected.

6. See Lee's dedication of Euphorion to Walter Pater.

7. Vernon Lee, "Les Aventures d'une Pièce de Monnaie," La Famille (May, June, July 1875): 233-37, 268-71, 327-34. This story draws on the tradition of the "itnarrative" or "object-tale," a popular genre of the eighteenth century, stories in which coins, carriages, animals, and other objects engage in autobiographical narration. Christopher Flint associates the object-narrative with burgeoning commodity fetishism and links the genre to authorial concerns about the circulation of books ("Speaking Stories: The Circulation of Stories in Eighteenth-Century Prose Fiction," 
PMLA 113 [March 1998]: 212-26). Jonathan Lamb argues that object-tales and stories of metamorphosis expose the implicit violence and perversity in the enlargement of sympathy ("Modern Metamorphoses and Disgraceful Tales," Critical Inquiry [Autumn 2001]: 133-66). For a discussion of object-tales concerned specifically with coins, see Deirdre Lynch, The Economy of Character: Novels, Mass Culture, and the Business of Inner Meaning (Chicago: University of Chicago Press, 1998), 96.

8. Walter Pater, The Renaissance: Studies in Art and Poetry, The 1893 Text (Los Angeles: University of California Press, 1980), xx.

9. Carolyn Lesjak locates a utopian promise in Wilde's idea of the collection that might be compared to Lee's concern with the separateness of objects. Lesjak argues that Wilde's collected object is "liberated from the drudgery of use-value" and that this liberation "maintains the integrity of objects and, crucially, makes possible an intimate relationship to them." However, because Lee's attempt to acknowledge the alterity of objects relies initially upon a consideration of their historical otherness, it is the collection that stands in her ghost stories, such as "Winthrop's Adventure," for all that is wrong with current modes of consumption. For Lee, collecting extracts objects from history and rearranges them according to the tastes of the consuming subject (Lesjak, "Utopia," 186).

10. Gordon Bigelow, Fiction, Famine, and the Rise of Economics in Victorian Britain and Ireland (New York: Cambridge University Press, 2003), 182.

11. Bill Brown, "The Secret Life of Things: Virginia Woolf and the Matter of Modernism," Modernism/Modernity 6, no. 2 (1999): 3.

12. In "The Secret Life of Things," Brown describes the "modernity Simmel renders" as a moment when "the ability to dominate things is coupled with the inability to establish contact with things" (9). Lee is preoccupied with a similar dynamic in which an aggressive, individualist mode of object relations has also inhibited the perception of objects. See also Rosemary Coombe's recent work on intellectual property law, which examines the manner in which categories of cultural property reproduce the logic of individualism (The Cultural Life of Intellectual Properties: Authorship, Appropriation and the Law [Durham, NC: Duke University Press, 1998]).

13. Taine argues: "In our time the overloading of the human mind, the great number of contradictory doctrines, the excess of cerebral activity, the sedentary habits, the artificial mode of life, and the feverish excitement of great centres, have exaggerated the nervous activity, have originated a craving for new and violent sensations, have developed vague sadness, wistful aspirations, and boundless desires ... [Man] is continually receiving shocks which disarrange his physical structure and break down his bodily health ... Sated and fickle, he asks art to give him new and strong impressions, new effects of colouring, new types of faces and of scene, accents which, at any price, can move tickle or amuse him" (qtd. in Vernon Lee, "Taine's Philosophy of Art," British Quarterly Review 68 [July 1878]: 14).

14. Lee, "Taine's Philosophy," 15.

15. Ibid., 16.

16. See Regenia Gagnier, The Insatiability of Human Wants (Chicago: University of Chicago Press, 2000). 


\section{Haunted Collections: Vernon Lee and Ethical Consumption}

17. Vernon Lee, "Ruskinism," in Belcaro: Essays on Sundry Aesthetical Questions (London: W. Satchell, 1881), 226.

18. Recent readings of Miss Brown emphasize the novel's critique of aestheticism's reductive treatment of femininity. For example, Kathy Psomiades discusses Lee's rejection of "Pre-Raphaelite aestheticism's heterosexual imperative" in Miss Brown ("Still Burning from This Strangling Embrace': Vernon Lee on Desire and Aesthetics," in Victorian Sexual Dissidence, ed. Richard Dellamora [Chicago: University of Chicago Press], 22). Christa Zorn argues that Lee was both "attracted to and alienated by aestheticism" and that Miss Brown indicates that "Lee was troubled by a form of aestheticism that worshipped woman's sexual beauty but limited her self-determination" (Vernon Lee: Aesthetics, History, and the Victorian Female Intellectual [Athens: Ohio University Press, 2003], 115). Hilary Fraser argues that Miss Brown "reveals Lee's acute awareness of the constitution of woman as spectacle in the contemporary visual economy" ("Women and the Ends of Art History: Vision and Corporeality in Nineteenth-Century Critical Discourse," Victorian Studies [Autumn 1998]: 88). Though Lee defends "art for art's sake" in Belcaro, her highly critical representation of aestheticism's hedonist and misogynist tendencies in Miss Brown suggests that her relationship to the aestheticist credo was quite complicated.

19. Diana Maltz's discussion of Lee's ethical dialogues draws attention to the distinctly Ruskinian tone in Baldwin's reprimand of a decadent's desire to have strawberries in January, an act that would demand more work out of exhausted laborers. As Maltz notes, Lee came to believe that "a harmonious life was contingent in conscientious consumer choices" (Diana Maltz, "Engaging 'Delicate Brains': From Working-Class Enculturation to Upper-Class Lesbian Liberation in Vernon Lee and Kit AnstrutherThomson's Psychological Aesthetics," in Women and British Aestheticism, ed. Talia Schaffer and Kathy Psomiades [Charlottesville: University of Virginia Press, 1999], 219).

20. Vernon Lee, Laurus Nobilis: Chapters on Art and Life (London:John Lane, Bodely Head, 1909), 39

21. In her desire to preserve a consideration of pleasure in a moral approach to consumption, Lee might be compared to William Morris. Both Morris and Lee seem to have been pulled in different directions by aestheticism's hedonistic tendencies on the one hand and the moral commitment evident in Ruskinian and socialist thought on the other. While they both seem to have developed an increasingly complicated relationship to aestheticism, they also seem to have drawn on their experience with the Aesthetic movement in their attention to the significance of pleasure in their later works.

22. Lee's commonplace books are in the Colby College Special Collections in Waterville, Maine. Inside the cover of each individual commonplace book, Lee carefully notes which books she read and which books she wrote during that particular year.

23. Gagnier, Insatiability, 19-60.

24. For a discussion of the moral component of Marshall's economic thinking, see, for example, Ellen Franken Paul's Moral Revolution and Economic Science: The Demise of Laissez-Faire in Nineteenth-Century Political Economy (Westport, CT: Greenwood, 
1979), 219-69; or David Reisman's Alfred Marshall: Progress and Politics (New York: St. Martin's, 1987).

25. J. K. Whitaker, "The Evolution of Alfred Marshall's Economic Thought and Writings Over the Years 1867-1890," in The Early Economic Writings of Alfred Marshall, 1867-1890, ed. J. K. Whitaker (New York: Free Press, 1975), 9.

26. Reisman, Alfred Marshall, 8 .

27. Alfred Marshall and Mary Paley Marshall, The Economics of Industry (London: Macmillan, 1885), 17. All subsequent references to this book will be cited parenthetically in the text.

28. Lee, Euphorion, 149-51.

29. Ronald Schleifer, Modernism and Time: The Logic of Abundance in Literature, Science, and Culture, 1880-1930 (New York: Cambridge University Press, 2000), 111.

30. See Peter Osborne, The Politics of Time: Modernity and the Avant-Garde (New York: Verso, 1995); and Richard Terdiman, Modernity and the Memory Crisis (Ithaca, NY: Cornell University Press, 1993).

31. Terdiman, Modernity and the Memory Crisis, 53.

32. Gagnier, Insatiability, 48.

33. Exemplary marginalia include: Marx "does not see the word 'useful' shows that labour per se does not confer value," or, "Here the mistake is due to leaving out supply and demand." Lee's heavily annotated copy of Capital is in the Vernon Lee Library at the British Institute in Florence.

34. See, for example, Alon Kadish's assertion that most economists of the late nineteenth century were "unaware that the marginal revolution had taken place" (Historians, Economists, and Economic History [London: Routledge, 1989], 109); or Mark Blaug's statement that "the 'marginal revolution' ... went unrecognized by those who lived through it" (Economic Theory in Retrospect [New York: Cambridge University Press, 1985], 305).

35. Henry Sidgwick, The Principles of Political Economy (London: Macmillan, 1924), 1. All subsequent references to this book will be cited parenthetically in the text.

36. William Stanley Jevons, The Theory of Political Economy (London: Macmillan, 1888), 1 .

37. Ibid., 164

38. Susan Stewart, On Longing: Narratives of the Miniature, the Gigantic, the Souvenir, the Collection (Durham, NC: Duke University Press, 1993), 165

39. John Ruskin, The Political Economy of Art (London: Smith and Elder, 1868), 119. All subsequent references to this book will be cited parenthetically in the text.

40. The works of Walter Pater are frequently read as an outgrowth of the quickened temporality of consumer culture. For Regenia Gagnier, Pater operates as the primary aesthetic representative of the "promotion of subjectivism, individualism, consumption, and ultimately formalism" in "the transition from a productivist to a consumerist ideology" during the late nineteenth century (Gagnier, Insatiability, 54, 59). Rachel Bowlby makes a similar move to collapse Paterian doctrine and consumerist ideology, remarking that "the final sentence of the 'Conclusion' to The Renaissance is surely the last word in advertising technique. In its forceful promotion of the momentary personal pleasures promised by the object, it could be said to mark the beginning of con- 
sumer culture" (Just Looking: Consumer Culture in Dreiser, Gissing, and Zola [New York: Routledge, 1985], 24).

41. Walter Pater, Marius the Epicurean: His Sensations and Ideas (New York: Oxford University Press, 1986), 81, 87, 89

42. Ibid., 89 .

43. Ibid., 88 .

44. Walter Pater, Imaginary Portraits, ed. Bill Beckley (New York: Allworth Press, 1997), $98,97$.

45. Pater, Renaissance, 182.

46. This is not to say that Pater's works should be understood as a valorization of amoral pleasure-seeking and consumption. The subjectivism endorsed by Pater is in fact different from the subjectivist behavior associated with consumerism. Jonathan Freedman acknowledges that Pater's delineation of an ideal type of receptivity to experience might initially seem to resemble the behavior consumer culture demands of the self: "endlessly mobile receptiveness to an infinitely eddying succession of sensual experiences" and the "desire to master the bewildering and predatory imperatives of the market by an acquisitive or possessive gesture of mind. However, Freedman argues that Pater's model of aesthetic consciousness in fact works to disrupt the impulses of consumerist subjectivity, for it "refuses to be captured by any one sense experience; endlessly mobile, indeed acutely hyperkinetic, it comes into being under the injunction to refuse any sense of 'possession or leverage in an indeterminate situation.'" Freedman's reading teases out a fundamental distinction between Paterian spectatorship and consumerist desire. The former altogether lacks the acquisitive or possessive impulse of the latter (Jonathan Freedman, Professions of Taste: Henry James, British Aestheticism, and Commodity Culture [Stanford, CA: Stanford University Press, 1990], 68-69).

47. Angela Leighton, "Ghosts, Aestheticism, and Vernon Lee," Victorian Literature and Culture 28, no. 1 (2000): 1.

48. Walter Benjamin, "On Some Motifs in Baudelaire," in Illuminations (London: Fontana Press, 1992), 152-96.

49. Miriam Hansen, "Benjamin and Cinema: Not a One-Way Street," in Benjamin's Ghosts: Interventions in Contemporary Literary and Cultural Theory, ed. Gerhard Richter (Stanford, CA: Stanford University Press, 2002), 44-45.

50. Stewart, On Longing, 153. Stewart draws the concept of an "aesthetics of mercantilism" from an article by James H. Bunn, "The Aesthetics of British Mercantilism," New Literary History 11, no. 2 (1980): 303-21.

51. Remy G. Saisselin, The Bourgeois and the Bibelot (New Brunswick, NJ: Rutgers University Press, 1984), xv.

52. Lee refers to Venice in this way in Genius Loci: Notes on Places (London: Grant Richards, 1899), 107. Lee's concept of the "genius loci" could be understood as another method of combating the elision of alterity and history in modern consumer practices. By emphasizing the "spirit of place," she encouraged travelers and tourists to truly engage with the difference of the locations they visited.

53. In "In Quest of a Museal Aura," Ruth Hoberman reads Lee's supernatural fiction in a very different manner, suggesting that characters who read works of art in relation to 
their historical contexts die in the ghost stories, because Lee believed that viewing a work of art "in the object's original setting ... where its aura is powerful enough to immerse the viewer in the past" is undesirable. I read haunting, terror, and murder in Lee's ghost stories as allegorical representations of destabilizing aesthetic encounters. Hoberman argues that Lee thought one could perceive and understand the formal qualities of a work of art more effectively when that object had been isolated from its contexts—in a museum, for example. As my reading of "Amour Dure" indicates, Lee associated historicized consumption with refined or sharpened vision.

54. Vernon Lee, "Amour Dure," in Hauntings: Fantastic Stories (London: Heinemann, 1890), 4. All subsequent references to this story will be cited parenthetically in the text.

55. For a discussion of this story in relation to concerns about the limitations of patriarchal historiography, see Zorn, Vernon Lee, 167. Peter Christenson argues that in "Amour Dure," Lee creates "a woman who exists as a cipher, a problematic projection of male desire." He reads the story as raising questions about "whether this woman is actually evil or whether it is man who portrays her as evil." See "The Burden of History in Vernon Lee's Ghost Story 'Amour Dure," Studies in the Humanities 16, no. 1 (June 1989): 33-43.

56. Zorn, Vernon Lee, 162.

57. Hansen, "Benjamin and Cinema," 45.

58. Jean Baudrillard, "The System of Collecting," in The Culture of Collecting, ed. John Elsner and Roger Cardinal (Cambridge: Harvard University Press, 1994), 22.

59. Ibid., 8.

60. Lee, Laurus Nobilis, 27. All subsequent references to this book will be cited parenthetically in the text.

61. Vernon Lee, "Winthrop's Adventure," in For Maurice. The story first appeared in Fraser's Magazine in January 1881. All subsequent references to this story will be cited parenthetically in the text.

62. For a more extended discussion of overwhelming encounters with voices in Lee's works, see Patricia Pulham, "The Castrato and the Cry in Vernon Lee's Wicked Voices," Victorian Literature and Culture 30, no. 2 (2002): 421-37. Pulham reads the figures of castrati in Lee's stories as ghostly symbols of "empowerment for the lesbian writer who must masquerade as male and negate her sexuality" (435).

63. Vernon Lee, The Beautiful: An Introduction to Psychological Aesthetics (Cambridge: Cambridge University Press, 1913), 1. All subsequent references to this work will be cited parenthetically in the text.

64. Fraser, "Women and the Ends of Art History," 94. See Anne Mellor, Romanticism and Gender (New York: Routledge, 1993).

65. Brown, "Secret Life of Things," 5.

66. Ibid.

67. Bill Brown, "Thing Theory," Critical Inquiry 28, no. 1, Things (Autumn 2001), 3.

68. Ibid.

69. Ibid., 4 .

70. George Leonard argues that "a change without precedent in the history of art occurred around 1800: the reversal of rank between art objects and real things" (Into the Light 
of Things: The Art of the Commonplace from Wordsworth to John Cage [Chicago: University of Chicago Press, 1994], 104). His reading of Modern Painters emphasizes the extent to which Ruskin understood "art objects as 'transcripts' to aid us in the study of mere real things" (104).

71. As Brown notes, Theodor Adorno understands "the alterity of things as an essentially ethical fact. Most simply put, his point is that accepting the otherness of things is the condition for accepting otherness as such" (Brown, "Thing Theory," 9).

72. As Kathy Psomiades argues, this concern is evident in her critique of pre-Raphaelite aestheticism's "use of the female body as the raw material for an art that exploits women as objects of heterosexual masculine desire" ("Still Burning," 22).

73. A critique of collecting that resembles and predicts the analysis of the practice in the works of Baudrillard, Stewart, and Saisselin is similarly evident in the works of many of Lee's contemporaries, such as Henry James and Oscar Wilde. For a discussion of the treatment of collecting in the works of James and Wilde see, for example, Peter Donahue's "Collecting as Ethos and Technique in The Portrait of a Lady," Studies in American Fiction 25, no. 1 (Spring 1997): 41-56; or Rita Felski's assertion that in the collections of Duc Jean des Esseintes and Dorian Gray "history has become a museum of eclectic and random artifacts that narcissistically mirrors [their] own fantasies and preoccupations" (The Gender of Modernity [Cambridge: Harvard University Press, 1995], 99).

74. Bigelow, Fiction, Famine, 183. 